\title{
Estimation Tourism Use Value of Galy Ali Begg Waterfall, Kurdistan Region, Iraq
}

\author{
${ }^{1}$ Haji Y. Haji, ${ }^{2}$ Abdulah H. Al- Dabash \\ ${ }^{1,2}$ Department College of Agriculture, Forest Department, University of Dohuk, Kurdistan Region-Iraq
}

\begin{abstract}
In this paper the tourism value of Gally Ali Begg waterfall has been estimated by using Individual Travel Cost Method (TCM). A questionnaire was used for the survey to obtain the tourist value of this touristic site. Multiple linear regression analysis model has been developed using individual travel cost method. The results of the study show that the tourism value of Gay Ali Begg waterfall (consumer surplus) per person per year as is (6259ID)( US\$5.1)and the total consumer surplus for the study sample estimated as (9008353 ID)(US\$7354). One of the most significant findings that emerge from this study is that the relationship between numbers of visits of person per year (depended variable) and visitor education level is negative as opposed to previous studies. Taking together, these results suggest the public goods should be managed to maximize the public benefits and natural tourism is in fact a public benefit from the environment.
\end{abstract}

KEY WORDS: Tourism value, Travel cost method, Kurdistan region,Galy Ali Begg Waterfall, Natural tourism

\section{CHAPTER ONE}

\subsection{INTRODUCTION}

The estimation of the environmental services is one of the key elements of ecological sustainable development. According to Amirnejad H. (2005), the notion of evaluating the environment is something that must be done and this leads to the question being asked about the extension to which the environment could take place in financial terms. Newly, resource economists have begun the duty to estimating the contribution of natural tourism to human wellbeing. On the other hand, the protection of the natural tourism areas is widely considered as the basis of biodiversity conservation, providing ecosystem services to the public in addition to being a place for human tourism and entertainment which attract tourists from different destinations McNeely JA(1995). Depending on the World Travel and Tourism Council (WTTC,2014), in spite of tourism contributing to human welfare, tourism is an influential economic activity and one of the fastest and largest growing sectors of the world's economy, tourism and entertainment enhance peaceful co-existence and happiness of the individuals in the society (WTTC,2014). Most economists agree that one of the fundamentals of the economic project is to have an evaluation of the project. Depending on Alvarez S, Larkin L (2008) economic evaluation of natural tourism has been for both of tourist destination managers and for society in general, therefore some economic methodologies have been developed in the last decades to put value on nonmarkets environmental goods and services such as tourism value. Mehmet P, Türker MF (2006) State that the economic evaluation techniques can be used to measure the benefits related to environmental conservation projects and nature tourism activities. Through my interview with the tourism managers of Duhik, Rawandes, Shaqllawa, Suran and the director of the tourism authority in Kurdistan Region, there is no enough perception among the concerned people about the tourism value of natural touristic areas in Kurdistan region. 
Policy makers have agreed to the importance of taking in to consideration projects economic valuation when making decisions. It is vastly accepted that environmental goods and services can be quantified using different methods. Travel cost and contingent valuation method are the most common used methods. On the other hand quantify of environmental goods and services is remain relatively uncommon and the research published in this field in journal are very few. In spite of that, published research have explain that people in the developing countries also place values on environmental goods and the same methods in developed countries can be used in developing countries.

Adilli Z., Robert H N. (2016) Economic valuation of recreation use value of Kilimanjaro Park, Tanzania. The study focused on using the travel cost method to value recreation in KINAPA. Data were collected using questionnaire survey, key informants interviews and second materials. The questionnaire used for survey was designed to capture socio-demographic variables about visitor. The study conducted with the sample size of 384, The count data that were generated from survey was modeled with Poisson model. The result of the study showed that the consumer surplus per day of stay in park was 925182TZS (USD517.10), the mean visitor willingness to pay was per one day visit is $837280.8 \mathrm{TZS}$ ( USD516.84)the total recreation value of the park was estimated to be 314165955200TZS(USD193929602) per one year and the revenue maximizing entry fee for the park was estimated to be 90396TZS(USD55.8).In addition the results indicates that variable recreation income, age, employment status and the quality perception were significant and have an influence on the number of days visitor stay in the park.

Azam Abedini et al.(2016) used dichotomous choice Both single and double bounded dichotomous choice contingent valuation method with face to face interview and applied logit model in order to estimating the outdoor recreational value of lavizanJunglr park of Tehran. Results show that the average price for each visit to the park was estimated as 3696.1762IR.

Limae S. Mohammadi, Safari G. and Merceh G. Mohammadi (2017) used travel cost method to estimate the economics and recreational values, regression analysis was used to estimate some socio-economic variables on behavior of forest park visitors. The economic and recreational values of forest park calculated via the demand function and showed that the daily value of recreational site or consumer surplus is 6319800 Iranian rials.

A study by Haghani F., Azami A. (2017) used individual willingness to pay to estimate the economic value of historical monuments of Bisotun. The average willingness to pay to calculated for the economic value of Bistouns historical monuments based on logit and probit models is estimated to be 47659 .2Rials and 50149rials per visit respectively.

Individual travel cost method has been selected by zulpikar F., et, al.(2018)to estimate economic value of marine tourism in small island using travel cost method ( case study: untung jawa island, Indonisia). The study showed that the potential economic value of marine tourism untung jawa island was IDR 67505101600 with consumer surplus of IDR 397592 per individual per trip. A nother study carried out in Indonesia is suhel et, al.(2019). From the individual travel cost method suhel et, al. identifying the determining factors of recreation demand in Kongar lake of south sumetra. The consumer was (IDR 16.912) per visit and the annual recreational value include 1720 people who visited the lake annually over an area of ( IDR 5298288) per ha

\section{CHAPTER TWO}

\subsection{Research Methodology}

\subsubsection{Research problem}


Kurdistan region of Iraq possesses all the tourist elements including; cultural diversity, climate, landscapes, and archeological areas in addition to the security of Kurdistan in the volatile middle east. Tourism is often based on nature in Kurdistan region of Iraq, and the number of tourists increases year after year from 377397 tourists in 2007 to 3057642 tourists in 2018, and in Erbil Provence the number of visitors increased from 153571 tourists in 2007 to 1644942 in 2018 Tourism Strategic plan for Kurdistan Region of (Iraq) (2013). Despite of all the above, the economic values of all tourism elements are not completely quantified, this leads to the natural tourist destination to be naturally under estimated and the application of development becomes difficult to locate how much to invest. Galy Ali Beg waterfalls receive local visitors and visitors from other Iraqi provinces annually for tourism and recreation and the visitors would have a lot of expenditure in term of travelling costs, wasting time and other associated expenses, those expenses to visit Galy Ali Begg waterfall is an evidence that the waterfall has considerable tourism value. While marketplace goods and services are estimated in terms of their prices, environmental goods and services such as tourism, entertainment, and clean air. Moderated climate in the summer could be hard to estimate as they do not compound a market price.The implication of this problem can be clarified by asking the following question:

- 1-Are there economic value of tourism use of the natural tourism area in Kurdistan region?

- $\quad$ 2-Is the function of demand for natural tourism and factors influencing it in the Kurdistan Region assessed?

\subsubsection{Research Importance}

The importance of the research is to diagnose the economic value of natural tourism and assess the demand function of tourism and the affecting factors in it. The above points will contribute to provide a clear vision to the government and tourism directorates in the province of the region on economic importance of the tourist use of these sites and determine the requirements for tourist demand and the development of future plane to develop tourism in the region in general and in study destinations in particular.

\subsubsection{Research objectives}

this study aims :

- Estimating economic value of tourism use of Galy Ali Begg Waterfall destination by using individual travel cost method.

- Estimating tourism demand function and factors affecting on demand function.

- Find out visitor consumer surplus.

- Estimate visitors entrance fee as value of environmental services provided by tourist destination

\subsubsection{Research Hypothesis}

In the context of the interrelationship between the research problem, its importance and its objectives, the following hypotheses can be formulated:

- 1 - Tourist use of natural tourist destination in the Kurdistan region has economic value.

- 2 - The demand function for natural tourism and the factors influencing it in the Kurdistan region was not estimated.

\subsection{Sample research and data collection tools}

\subsubsection{Study Area}

Galy Ali Begg Waterfall : Situated about 95 Kilometers north of Erbil, on the road of Suran this valley dips between the Korek and Brado mountains. It is 12 kilometers long and contains many beautiful sites, including springs and waterfalls, Gally Ali Begg waterfall is a popular site for tourists from all around the country, it rises 800 meters above sea level and it locates 
at $36^{\circ} 38^{\prime} \mathrm{N}$ and $44^{\circ} 25^{\prime} \mathrm{E}$ and the temperature does not exceed $35^{\circ} \mathrm{C}$ in summer. General board of tourism, Kurdistan Region (Iraq) (2015),
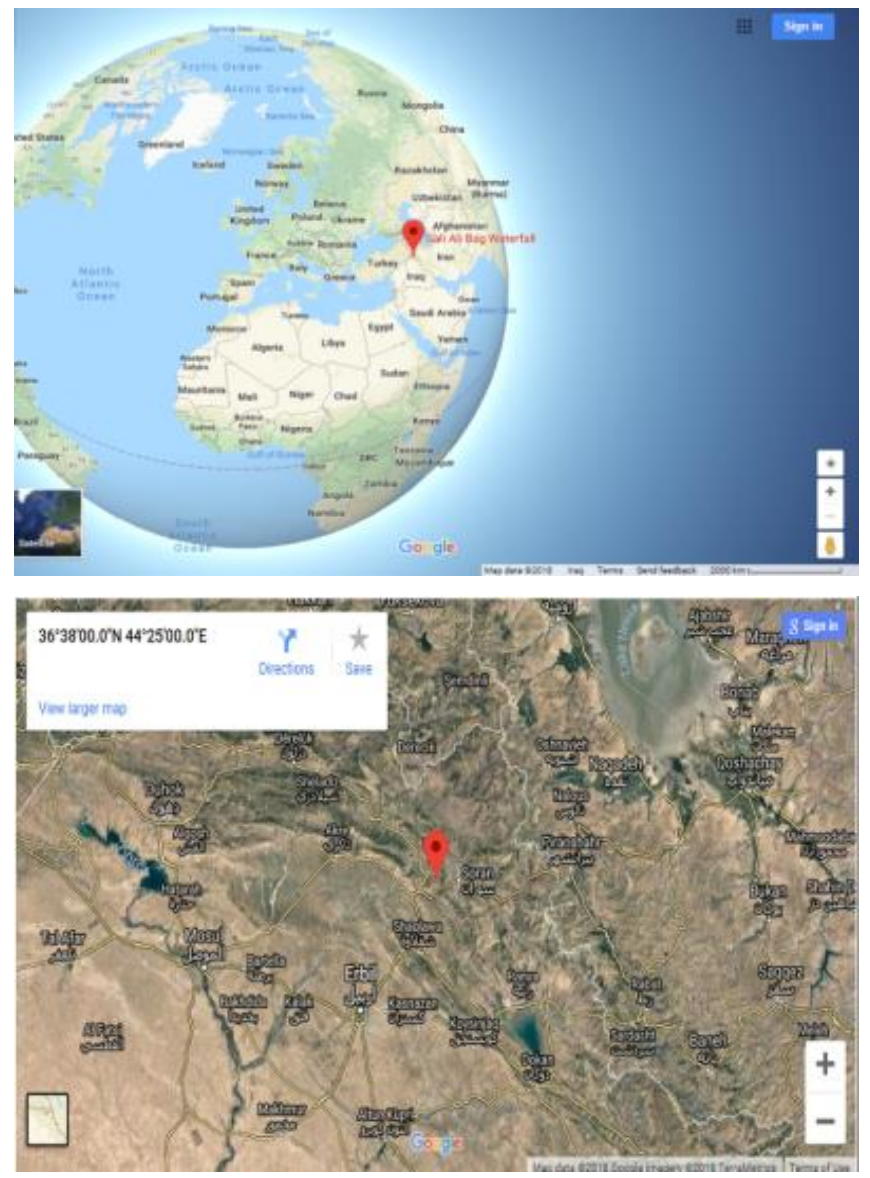

Fig.1. Gally Ali Begg Waterfall location

\subsubsection{Questionnaire Design and Data Collection}

The questionnaire was design to collect information about the travel cost method; it is conducted through face to face interviews with the tourists at the study location. The individual Travel Cost Method (TCM) is adopted for travel cost method in this study. The Questionnaire was designed cautiously in order to obtain the maximum reliable and valid study results. A preliminary test was conducted on June 25-2017, before the main survey to examine the suitability of the designed questions, the chosen population in the main survey were the visitors of Gally Ali Begg waterfall. Because it was unfeasible to include all visitors, therefore I needed to only conducted a limited number of interviews for the questionnaire. Iinterviewed386 respondents for the questionnaire, after the analysis of the preliminary test the main survey questionnaire was conducted, it was carried out from first July to September, 11, 2017, between 10:30' am and 7:30 pm.

The questionnaire consists of two sections, personal information and trip information. The first section includes personal information that contains respondents' age, gender, education, job, marital status, number of family members, and monthly income. The second section is about the places that the tourists come from, number of trips taken to the tourist destination during the season, travel expenditure including the accommodation fee, different travel vehicles they used, their weights on certain destinations and relative information and attitudinal questions towards the tourist destination. The public target of the questionnaires carried out in the process of survey study where the visitors of Gally Ali Begg waterfall were started from the age 18year.From 386 questionnaires were applied in the field, just 260 questionnaires were evaluated for the economic analysis in order to implementation of the travel cost method. The data was transport to the numeric form using the SPSS Version 23 for windows program and thus, it was created in to database.

\subsubsection{Data analysis}

Depending on Bell FK, Leeworthy VR (1990) most researches and economists considered individual travel cost method as better option of evaluate the tourism value, therefore, to attain the study objective of the estimating economic value of the tourist in Gally Ali Begg waterfall we used the Individual Travel Cost Method. The total economic value of an entertainment site is estimated as a function of use values related with consuming or enjoying an environmental goods or services according to Tietenberg T, Lewis L (2012) this is represented mathematically as: 


$$
\mathrm{Vij}=(\mathrm{Cij}, \mathrm{Xi})
$$

Where, $\mathrm{Vij}$ is the number of visits made per year the individual $\mathrm{i}$ to tourist site $\mathrm{j}$; Cij: visit cost by the individual i to tourist site $\mathrm{j}$; $\mathrm{Xi}$ : all other socio-economic variables determining individual visits. For the individual travel costs estimate Hanley and Spash Hanley N., Spash C. (1993). equation is used which as represented as below:

$$
\mathrm{TTC}(\mathrm{ij})=\mathrm{b} 0+\mathrm{b} 1^{*} \mathrm{Tr}(\mathrm{ij})+\mathrm{b} 2{ }^{*} \mathrm{Acc}(\mathrm{ij})+\mathrm{b} 3{ }^{*} \mathrm{TI}(\mathrm{ij})+\mathrm{b} 4{ }^{*} \mathrm{~S}(\mathrm{ij})+\mathrm{b} 5^{*} \mathrm{Fj}+\mathrm{Uij}
$$

Where, TTC(ij)-Is the total costs of individual i to visit site j. $\operatorname{Tr}(\mathrm{ij})$-Round travel cost for individual i to visit site j . Acc(ij)- Accommodation cost for individual I to visit site j. TI(ij)- Time cost spend for travel and inside touristic area for individual i to visit site $\mathrm{j}$. S(ij)-Is the onsite expenditures for individual $i$ at site $j$. Fj-Is the entry fee to the site $\mathrm{j}$. Uij represent the unobserved factors of individual I visiting site $\mathrm{j}$. The data where entered in Statistical Package for Social and Science (SPSS) version 23.Regresion analysis assessed socioeconomic factors that may affect visitation of an individual to the touristic destination (Vij) such as total travel costs(TTC),Income (IN), Education Level(E), Age(Ag), Satisfaction of the tourist destination (SAT)and unobserved factors Uij, against the number of annual visits as a dependent variable, this gives the demand function of the tourist destination as shown in the equation(3)

$$
\mathrm{Vij}=\mathrm{b} 0+\mathrm{b} 1^{*} \mathrm{TTC}+\mathrm{b} 2{ }^{*} \mathrm{IN}+\mathrm{b} 3{ }^{*} \mathrm{E}+\mathrm{b} 4^{*} \mathrm{Ag}+\mathrm{b} 5^{*} \mathrm{SAT}+\mathrm{Uij}
$$

\subsubsection{The consumer surplus}

Consumer surplus is defined as the differences between the total amounts of the consumer that are willing and able to pay for a goods and services (indicated by the demand curve) and the total amount that they actually do pay (market price) www.tutore2u.net/economics /reference/consumer. In other words, the consumer surplus was the benefit that supplied through the balance price (market price) for the consumer. For causation of consumer surplus, annual visiting number was taken as the dependent variable, whereas socioeconomic characteristics of visitors and travel features were selected as the independent variables. For calculation of time opportunity cost I depended on Cesario suggestion which is based on $1 / 3$ of hourly wages rates Winkle CV. (2013) and the equation 4 were used to calculate consumer surplus.

$$
C S=-q / b 1
$$

q- Average of total annual number of visits

b1- Curve of the demand function(travel costs confident)

From the demand function as used by Winkle Winkle CV. (2013), Blackwell Blackwell B. and Ortacefilm et al., Ortaçefime V, Özkan B, Karagüzel $\mathrm{O}(2002)$, the consumer surplus is estimated using the following formula:

$\mathrm{CS}=-\mathrm{q} / \mathrm{b} 1$

(5) for log and semi-log function.

$\mathrm{CS}=-\mathrm{q}^{2} / 2 \mathrm{~b} 1$

(6) For Linear function.

Where, CS is the consumer surplus. b1-is the Coefficient of total travel costs. The total annual consumer obtained from the tourism site can be calculated by multiplying the individual consumer surplus with the number of visits made in a year. The consumer represents the tourism value of the tourist destination.

\section{CHAPTER THREE}

\subsection{Natural Tourism important and classification}

\subsubsection{Natural Tourism important}

Tourism is the biggest International industry in the world as stated in number on employment and expenditures. More than $(1,323)$ billion people, the equivalent of nearly $17.5 \%$ of the world population, travel internationally every year with many more traveling with their countries habitation(UNWTO2017) .Airlines, the accommodation and restaurant business and recreation equipment industrialist and sellers are among provider industry that are highly conditional on 
a successful tourism sector. On the other hand tourism rely on and provides income to national infrastructures such as airports, rail system, roads, networks, electric power systems, agricultural produce and water provision systems. On a more personal measure, traveling provides individual with the opportunity to escape temporarily from the routine of every-day life, to test unusual or unknown and, perhaps, to make a longtime "dream come true. Find out the world a arguably figures amongst the top life goals for many people in developed countries. Therefore the tourism sector entirely seems to be fairly resilient to disruptions from economic downturns, political crisis, extreme weather events, or even natural disaster (UNWTO press release, 2006).

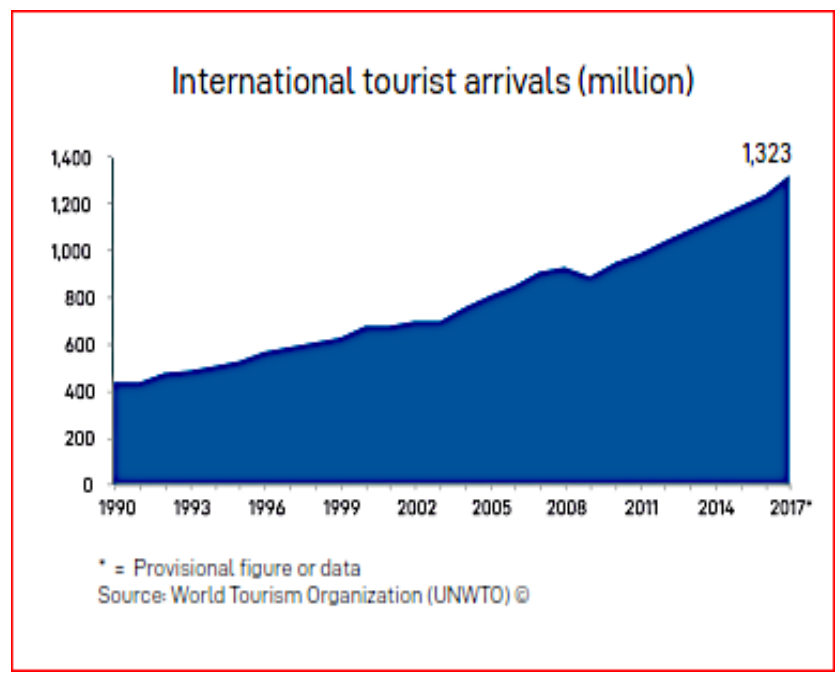

Fig. 2. International tourist arrival

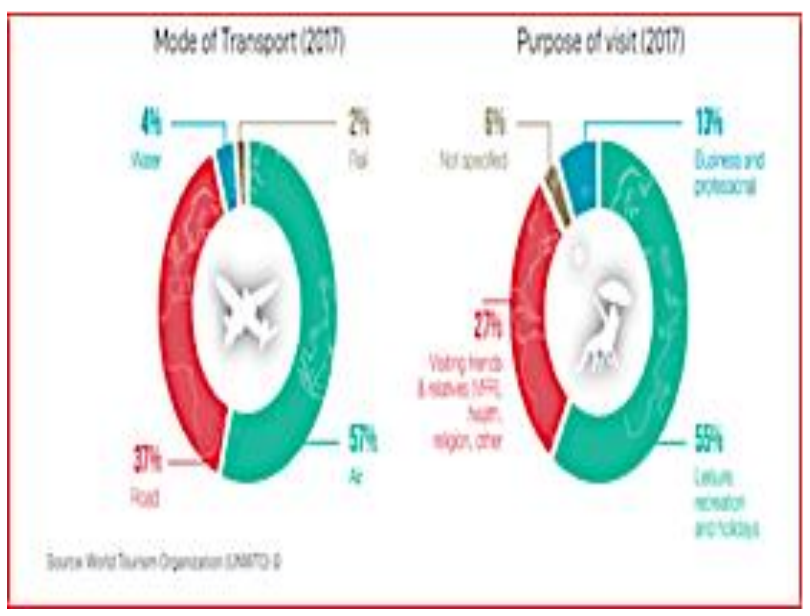

Fig. 3. mode of transport2017.
Depend on the preliminary full-year results reported in the issue of united nation world tourism organization barometer 2018, the international tourists arrivals grew surprising 7\% in 2017 to reach a total of 1,322 million, from this total number of visitor $55 \%$ are for leisure, recreation and holydays purpose, $27 \%$ visiting friends and relative, health, religion, other. And 13\% are for business and professional purpose while 6\% not specified. Tourism industry provides a job opportunity for one in ten individual and made up $10 \%$ of world GDP, tourism industry constitutes $30 \%$ of exported goods and $7 \%$ of world exports. In term of transportation mean, The most of tourists traveled by air transportation which mad up $57 \%$ followed by $37 \%$ traveled by road mode.

The most important form of tourism rising today is natural based tourism. It is becoming a large international industry with major economic, social and environmental effect on local and global scale (BuckleyPickering- Waver 2003,1),Meyer and Arendt 2004 as cited in(Olafsdottir 2013,127) explain that nature based tourism history has relatively short, if we compare with other type of tourism for example cultural tourism and traditional tourism. At the first tourism and travel was the trip to see the Seven Wonders of the World. The framework of tourism has changed today there are different reasons for traveling as tourists. In this account Pearce, Morrison and Rutledge, 1998 as mention in (LuoNeng 200 ,393)found that out of 10 important push of tourist. For were belong to the nature based tourism and they where dissenting to experience the environment. In natural based tourism, remoteness, cultural identity, and environment make the destination gets priority. Johnston 1990 as mention in (selverberge-Backman 1996, 20).

Nature plays an important role in tourism as it gives push to travel and also is the location where tourism 
activity take place(Edward-Benediktsson 2013,190) this reflects that together with the nature beauty of the destination on nature based tourism, the human features like culture and hospitality of the people living in destination place also play an important role ,for this reason ,it is important to select the destination depending on its location and cultural identity of the people. In addition to the natural characteristics, the economic and social activity connected to tourism at the destination place should also be considered for successful nature based tourism (Bockley 200,236).

Natural tourism indicate all type of tourism directly rely on the use of natural resources in a comparatively undeveloped stat, including wildlife recreation, scenery, topography, and water features .thereby it includes hutting, countryside motor biking, and water rafting ,even if the use of natural resources by tourists is neither wise nor sustainable (Bulter,1992;Ceballosslascorrain;1987,Healy,1992b).same as traditional tourism, nature based tourism can be negatively Influenced by various external factors this is the reason for its instability as a source of income.

\subsubsection{Types and form of tourism}

\subsubsection{Tourism classification}

In 1939 in poser was the first appear of tourism characterize, the paper :"Der fremdenverkehr im Riesengebirge" .Here, poser recognize several type of tourism: tourism by transit, summer relaxation, winter sport, short distance relaxation. Also in 1941 Hunztiker and Krampf distinguish several type and form of tourism: travel for rest and treatment, pilgrimage, and scientific knowledge,etc. (source: types and forms of tourism.

Finally in 1965, julg, Ruppert and maierin1970.confussed the presence of six types of tourism:

i. Recreation tourism.

ii. Therapy(Relaxation and health Care tourism) iii. Visitation.

iv. Reduced distance relaxation.

v. Transit tourism,

vi. Professional tourism.

United Nation World Tourism Organization Classified Tourism as:

Domestic tourism:

Refer to the trips made by local people with their own countries.

International Tourism: It refers to the trips between two countries. to a certain country, visit by local people of that country to another country is here outbound tourism, visit to the country by residents of another country is here inbound tourism.(UNWTO,2008)

Dissimilar the types of tourism, the forms of tourism represent the way to conduct the tourism building on the causes and the outer impacts. The forms of tourism have as their destination the characteristics of tourism. Depend on the following criteria we recognize several form of tourism.

\section{CHAPTER FOUR \\ RESULTS AND DISCUSSION}

\subsubsection{Socioeconomic Characteristics of the Tourist}

Descriptive statistics of vital variables (dependent and independent variables) collected from the visitors that were present in Gally Ali Begg waterfall destination are real in table(1).Number of visits to the site (Gally Ali Begg waterfall) by tourists during the summer season was a dependent variable, the plurality of tourists originated from Iraqi governorates. All of the visitors in the sample visited the site with unique purpose of enjoying the tourist benefits.

As shown in Table (1) most of the tourists at Gali Ali Begg Waterfal were aged between 18 and 30 (45.8\%) followed by those between 31 and 40 (21.5\%), then above $40(18.5 \%)$ and lastly between 51 and 60 (10\%). This means that people aged between 18 and 30 are more 
interested in visiting the tourist destination as they are the make up the majority of visitors. Where visitors analyzed according to gender, the observations showed that the park receives more male visitors $(81.2 \%)$ than females $(18.8 \%)$. This implies that males are more interested in visiting natural tourism areas than females. It was seen that $54.2 \%$ of the Galy Ali Begg visitors were graduate and post graduated from university and 21.9\% were from high school this situation showed that there was positive relationship between education level and the using Gali Ali Begg waterfall for tourism purpose.

Table 1

Travel cost method according to the results of the demographic distribution survey. Variable frequency, percentage, mean and standard error (SE) have been calculated.

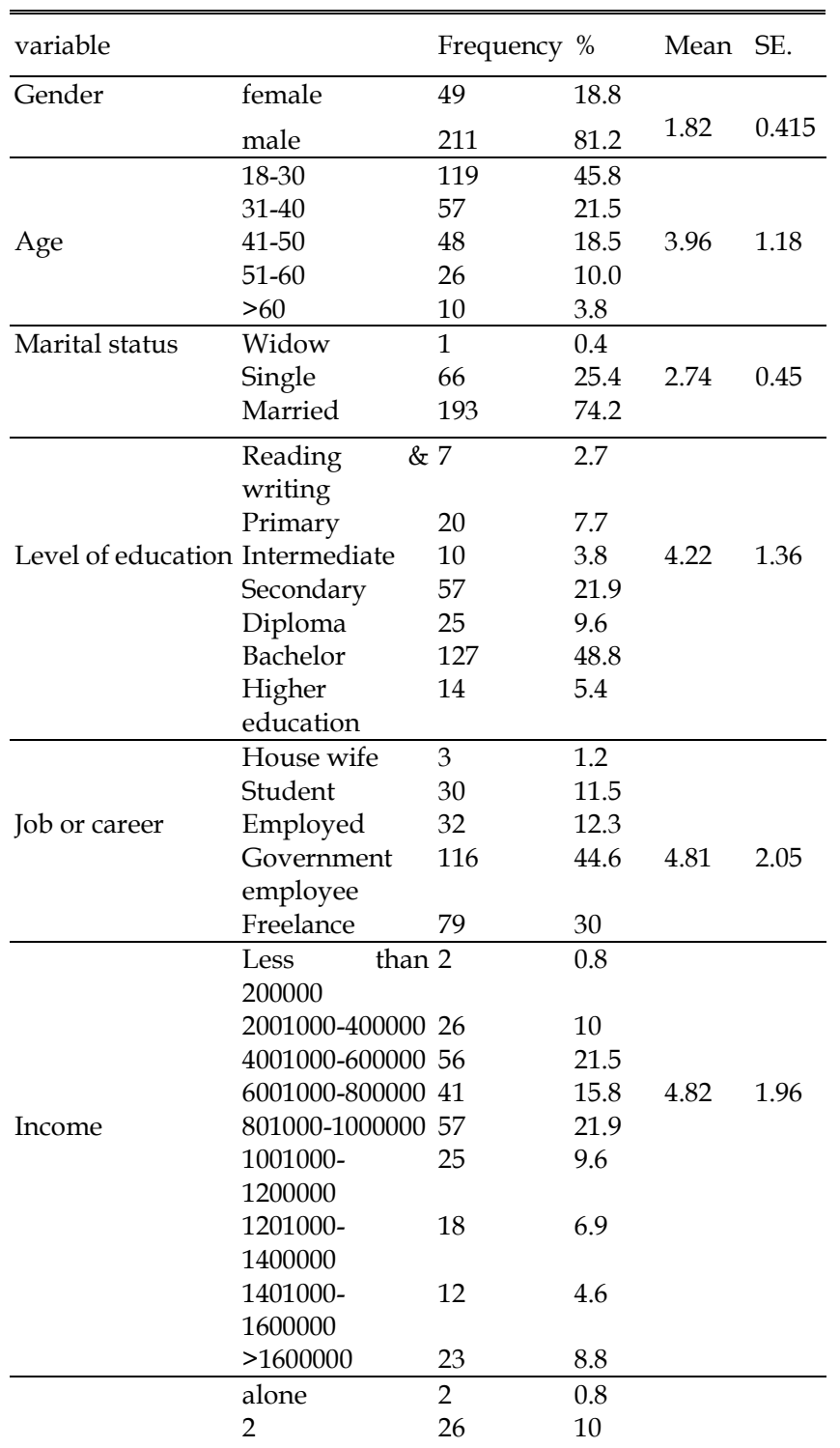

\begin{tabular}{|c|c|c|c|c|c|}
\hline \multirow{2}{*}{ Number of famil } & 3 & 56 & 21 & \multirow{7}{*}{4.2} & \multirow{7}{*}{2.46} \\
\hline & & 41 & 15.8 & & \\
\hline \multirow[t]{5}{*}{ Member } & 5 & 57 & 21.9 & & \\
\hline & 6 & 25 & 10 & & \\
\hline & 7 & 18 & 6.9 & & \\
\hline & 8 & 12 & 4.6 & & \\
\hline & 9 & 23 & 8.8 & & \\
\hline \multirow{5}{*}{$\begin{array}{l}\text { Total number o } \\
\text { visits }\end{array}$} & First time & 176 & 67.7 & \multirow{5}{*}{1.64} & \multirow{5}{*}{1.11} \\
\hline & Two times & 36 & 13.8 & & \\
\hline & Three times & 25 & 9.6 & & \\
\hline & Four times & 11 & 4.2 & & \\
\hline & Five times & 12 & 4.6 & & \\
\hline \multirow{6}{*}{$\begin{array}{ll}\text { satisfied } & \text { With } \\
\text { Gally Ali Begg } \\
\text { tourism area }\end{array}$} & Very & 9 & 3.5 & \multirow{6}{*}{2.29} & \multirow{6}{*}{0.57} \\
\hline & Unsatisfied & & & & \\
\hline & Unsatisfied & 173 & 66.5 & & \\
\hline & Neutral & 73 & 28.1 & & \\
\hline & Satisfied & 4 & 1.6 & & \\
\hline & Very satisfied & 1 & .4 & & \\
\hline
\end{tabular}

Where visit tourists analyzed according to their profession groups: $44.6 \%$ of visitors were government employee, $30 \%$ were freelancer. $15.8 \%$ had an annual income between \$ 490-653, 21.5\% had \$ 327-490 and $21.9 \%$ had $\$ 653-816$. The most important independent variable that determined the consumer surplus in travel cost method was the travel costs, it is taken as the total travel costs. In this study the individual travel cost for each person per visit to this destination ranges between $\$ 32.26$ and $\$ 3.82$, with average $\$ 11.3$ for each visit to Galy Ali Begg waterfall destination. From table one we show that $(1.6 \%)$ of respondents rated goods and services provided at Galy Ali Begg tourist destination "satisfied". While $(66.5 \%),(28.1 \%)$ say unsatisfied and neutral for goods and services provided at Galy Ali Begg respectively. The number of individual visits during one year was taken as dependent variables, A single annual visit to Gally Ali Begg Waterfall was the most public rate at $67.7 \%$, visiting twice per year was $13.8 \%$, three visits was $9.6 \%$ per year, and four and five visits were $4.2 \%, 4.6 \%$ respectively. Visitors analyzed according to original areas that they came from, $86.9 \%$ of visitors came from Iraqi governorates and 13.1\% from Kurdistan Region.

\subsubsection{MULTIPLE LINEAR REGRESION MODEL}

Table(2) States the result of the travel costs regression models for Galy Ali Begg waterfall tourist destination. 
All variables have expected signs.travel cost afford by individuals is negatively related to tourist destination visitation rates which mean higher the travel costs paid by visitors to reach the destination, the lesser the frequently of their visits. A results of multiple regression model come on that the estimated coefficient of travel costs (TTC) variable has expected negative sign and significant at $1 \%$ level, this is Identical to the concept of economic theory. (see Table 2). The negative singe of travel costs variables coefficient indicated a descending slop of demand curve visitor take less visit as travel costincreases. The coefficient of the total travel costs(TTC)was( -0.172$)$ it reveal that, with a thousand Iraqi Dinar increase in travel costs the expected number of visits(Vij) to the site decreased $172 \%$. Whilst holding the all other variable constants in the model. Also, we found that the age and education level have negative relationship and significant influences at $1 \%$ on the demand for tourist visit to the site with coefficient $0.565,0.047$ respectively., Income and satisfaction with the tourist destination affected to the number of visits positively and significantly with coefficient $(1.086$, and 0.167) respectively. In this study and in the used model (multiple linear regression model), It was shown that the independent variables such as travel costs, education level, age and satisfaction with tourist destination clarifies that $91 \%$ of visitors to the Gally Ali Begg waterfall destination for tourism purposes depend on independent variables specified in the model.

$\mathrm{Vij}=0.768-0.172(\mathrm{TTC})+1.086(\mathrm{IN})-0.047(\mathrm{EL})-0.565(\mathrm{Ag})+0.167(\mathrm{SAT})$

Table 2

Multiple regression Analysis Result Travel cost model.

\begin{tabular}{llll}
\hline \hline Variable & Coefficient & t-value & sig. \\
\hline Constant & 1.193 & 4.498 & 0.000 \\
Total travel cost & -0.215 & 5.080 & 0.000 \\
Age as number & -0.485 & 11.594 & 0.000 \\
Income as number & 1.111 & 21.602 & 0.000 \\
Education level & -0.157 & 4.302 & 0.000 \\
Satisfaction & 0.106 & 2.705 & 0.007 \\
\hline $\mathrm{R}^{2}$ adj. & 0.92 & & \\
Sig. & 0.00 & & \\
\hline \hline
\end{tabular}

Source: Field survey conducted by Author.
Equation (6) used in the calculation of individual consumer surplus. According to this equation, the average visits of 260 tourists, who joined the analysis was (1.64) to the Gally Ali Begg waterfall destination for tourism purpose. Accordingly, the individual consumer surplus accumulated (ID 400100)there was no any official record about the number of annual tourists of the Galy Ali Begg Waterfall. Nevertheless, for study sample ( 260 ) local tourists visited Galy Ali Begg Waterfall and (193) are married with the average number (4.2) of family members and the remaining visitors are single then it would be collected that the total minimum consumer surplus was (3,598,160 ID ) the value of consumer surplus revealed the use value of the Galy Ali Begg waterfall destination. And we can.

$\mathrm{CS}=-\left((1.64)^{2} / 2^{*}-0.215\right)=6259$ ID. $(\mathrm{US} \$ 5.1)$

$\mathrm{CS}=((193 * 4.2)+67) * 6259 * 1.64=9008353$ ID $($ US\$ 7354)

According to the findings from this study for Galy Ali Begg Water Fall, the value of consumer surplus is about 6259 ID(US\$5.1) for person per visit. And the total annual consumer surplus for the sample study is 9008353ID (US\$7354). The tourism value estimated in this study affirms the importance of conservation of nature. Results of the study will become a crucial instrument for pragmatic policies of ecotourism development in the valley.

\section{CHAPTER FIVE \\ CONCLUSION AND RECOMMONDATIO}

\subsection{CONCLUSION}

Environmental goods and services cannot be bought and sold in the urban and rural market. Therefore, the market does not provide the price for environmental services. Consequently, economist and tourist expert provide appropriate methods for quantify/qualify environmental services e.g. tourism and entertainment services, etc. In this context, Gally Ali Begg waterfall was 
selected and individual travel cost method have been applied to guess the tourism value. The present project study showed a negative relationship between dependent variable (individuals visit per year) with total trip costs and age and education level; in contrast, income and satisfaction with tourist destination have positive relationship with individual visit per year. On the other hand, all independent variables (travel costs, age, number of family member, and satisfaction with the tourist destination) have significant impact on dependent variable (individual visitation per year). The average of individual round trip costs was found to be 13635 ID (11.4\$) and the individual consumer surplus was guessed to be $6259 \operatorname{ID}(\mathrm{US} \$ 5.1)$. Furthermore, the tourist value for the study sample of the tourist destination estimated to be 9008353ID (US\$7354). The present research project has thrown up many questions in urgent need for further investigation in tourism value sector.

\subsection{RECOMMONDATIO}

The results showed by this study can be used by future researchers, planners, investors and managers in planning and managing the tourist destination and other related tourist destination in Kurdistan Region of Iraq. What is now needed is a multi-disciplinary and crossnational collaboration to determine the right economical value of tourist use.

\section{REFRENCES}

1. Amirnejad, H. (2005). The Total Economic Value determination of north forests ecosystem of Iran with the emphasis on valuation of environmental-ecological and preservation values (Doctoral dissertation, M. sc. thesis in Agricultural Economics, Tarbiat Modares University. 237 pages.-Baral, N., Stern, MJ \& Bhattarai).

2. McNeely, J. A. (1995). Expanding partnerships in conservation. Island press.(1-10)

3. [3]- Hudman, L. E., \& Hawkins, D. E. (1989). Tourism in contemporary society: an introductory text. Prentice-Hall, Inc..

4. Alkurdi, M. I. (2013). Sustainable Rural Tourism in Iraqi Kurdistan Region: View From Shaqlawa Small Town.
Conference Current Problems of Landscape Architecture and Landscape Planning, Bratislava. http://www. fa. stuba. sk/docs/uzka/aktualne_prob_konf/Alkurdi. pdf.

5. Alvarez, S., \& Larkin, S. L. (2008). Valuing Recreational Benefits of a National Park in Andean Colombia (No. 13682016-108461)(P2-6).

6. [6]- Pak, M., \& Türker, M. F. (2006). Estimation of recreational use value of forest resources by using individual travel cost and contingent valuation methods (Kayabasi forest recreation site sample). Journal of applied sciences, 6(1), 1-5.

7. [7]- Braim, K. M., McCabe, S., Rickly, J., \& Gadi, M. (2016). Challenges that face cultural tourism development in conflict and post-conflict regions: the case of Kurdistan.

8. [8]- Bell, F. W., \& Leeworthy, V. R. (1990). Recreational demand by tourists for saltwater beach days. Journal of environmental economics and management, 18(3), 189-205.

9. [9]- Tietenberg, T. H., \& Lewis, L. (2016). Environmental and natural resource economics. Routledge.

10. [10]- Hanley, N., \& Spash, C. (1996). Cost benefit analysis and the environment.

11. www.tutore2u.net/economics/reference/consumer.

12. Bruce, R. D., Winkle, P., Custodio, J. M., Wei, L. X., Rhee, M. S., Kearney, B. P., ... \& Friedland, G. H. (2013). The pharmacokinetic and pharmacodynamic interactions between buprenorphine/naloxone and elvitegravir/cobicistat in subjects receiving chronic buprenorphine/naloxone treatment. JAIDS Journal of Acquired Immune Deficiency Syndromes, 63(4), 480-484.

13. Blackwell, B. (2007). The value of a recreational beach visit: An application to Mooloolaba beach and comparisons with other outdoor recreation sites. Economic Analysis and Policy, 37(1), 77-98.

14. ORTAÇEŞME, V., ÖZKAN, B., \& KARAGÜZEL, O. (2002). An estimation of the recreational use value of Kursunlu Waterfall Nature Park by the individual travel cost method. Turkish Journal of Agriculture and Forestry, 26(1), 57-62.

15. Zella Adili, Y., \& Ngunyali Robert, H. (2016). Economic Valuation of Recreation Use Value of Kilimanjaro National Park. Tanzania. J Ecosys Ecograph, 6(220), 2.

16. Abedini, A., Mohamadi, M. H., \& Sharahi, M. K. (2016). Estimating the Outdoor Recreational Value of Lavizan Jungle Park of Tehran Using Contingent Valuation Method (CV). Open Journal of Ecology, 6(05), 225.

17. Zandi, S., Limaei, S. M., \& Amiri, N. (2018). An economic evaluation of a forest park using the individual travel cost method (a case study of Ghaleh Rudkhan forest park in northern Iran). Environmental \& Socio-economic Studies, 6(2), 48-55.

18. Haghani, F. (2017). Determining the economic value of historical monuments of Bisotun using the method of individuals' willingness to pay (WTP). 
19. Zulpikar, F., Tambunan, L. A., Utami, S. R., \& El Kiyat, W. (2018). Economic Valuation of Marine Tourism in Small Island Using Travel Cost Method (Case Study: Untung Jawa Island, Indonesia). Omni-Akuatika, 14(1).

20. [20]- Suhel, S., Bashir, A., \& Yuliana, S. (2019). Identifying the determining factors of recreation demand in Kongar Lake of South Sumatera: An individual travel cost approach. Forest and Society, 3(1), 34-48.

21. Highlights, T. (2017). Edition, UNWTO (2017).

22. Hall, C. M. (Ed.). (2007). Pro-poor tourism: who benefits?: perspectives on tourism and poverty reduction (Vol. 3). Channel View Publications.

23. Buckley, R., Pickering, C., \& Weaver, D. B. (2003). Naturebased tourism, environment and land management. Cabi Publishing.

24. Resing, K. A., Meyer-Arendt, K., Mendoza, A. M., AvelineWolf, L. D., Jonscher, K. R., Pierce, K. G., ... \& Goehle, G. R. (2004). Improving reproducibility and sensitivity in identifying human proteins by shotgun proteomics. Analytical chemistry, 76(13), 3556-3568.

25. Olafsdottir, G. (2013): 127-138. On nature-based tourism.

26. Pearce, P. L., Morrison, A. M., Rutledge, J. L., Pearce, P. L., Morrison, A. M., \& Ruthledge, J. L. (1998). Motivation influence in tourism demand. Tourism: Bridges across continents. Roseville NSW, Australia: McGraw-Hill Book Company.

27. Kafle, N. (2014). NATURE BASED TOURISM AND VISITOR EXPERIENCES IN CHITWAN NATIONAL PARK.

28. Kim, S. R., Halden, R. U., \& Buckley, T. J. (2008). Polycyclic aromatic hydrocarbons in human milk of nonsmoking US women. Environmental science \& technology, 42(7), 26632667.

29. Butler, J. R. (1992, February). Ecotourism: Its changing face and evolving philosophy. In IVth World Congress on National Parks and Protected Areas, Caracas, Venezuela.

30. Ceballos-Lascurain, H. (1987). Estudio de Perfectibilidad Socioeconómica del Turismo Ecológico y Anteproyecto arquitectónico y urbanístico del Centro de Turismo Ecológico de Slan Kalan, Quintana Roo, México. México: Sedue.

31. Healy, K. E., \& Ducheyne, P. (1992). The mechanisms of passive dissolution of titanium in a model physiological environment. Journal of Biomedical Materials Research, 26(3), 319-338.

32. Hunziker, W., \& Krapf, K. (1941). Tourism as the sum of the phenomena and relationships arising from the travel and stay of non-residents. Publications AIEST Association International expert scientific tourism.

33. UNWTO, U. (2008). Climate change and tourism. Responding to global challenges. Madrid, UNWTO. 